WYDZIAL MATEMATYCZNO-PRZYRODNICZY

\begin{tabular}{|c|c|}
\hline $\begin{array}{l}\text { Cele nauczania języka polskiego w programie } \\
\text { nauczania dla gimnazjum państwowego }\end{array}$ & $\begin{array}{l}\text { Cele nauczania przyrodoznawstwa w programie } \\
\text { nauczania dla gimnazjum państwowego }\end{array}$ \\
\hline $\begin{array}{l}\text { Cele nauczania takje same jak dla wydziału } \\
\text { humanistycznego }\end{array}$ & $\begin{array}{l}\text { 1. Z punktu widzenia rzeczowego: przyswojenie } \\
\text { przez uczniów zgodnych z nauka pojęć o is- } \\
\text { tocie żywej na miejsce błędnych pojęć gmin- } \\
\text { nych, zatem: przyswojenie pojęcia o życiu } \\
\text { ustroju w zwiazzu z jego budowa i w zaleźno- } \\
\text { ści od środowiska; wstępne przygotowanie do } \\
\text { pojęcia pokrewieństwa i ewolucji; } \\
\text { 2. Z punktu widzenia wychowawczego: (cele } \\
\text { takie same jak na wydziale humanistycznym), } \\
\text { a ponadto: } \\
\text { - kształcenie umiejętności porównywania } \\
\text { i ujmowania analogii, wykrywania osobliwo- } \\
\text { ści, uogólniania, samodzielnego klasyfikowa- } \\
\text { nia, tworzenia realnych pojęć i definicji; } \\
\text { - przyzwyczajanie do ostrożności w rozszerza- } \\
\text { niu pojęć, zdobytych na pewnej liczbie wypa- } \\
\text { dków konkretnych, na inne wypadki, przez } \\
\text { wykazywanie wyjątów i w ogóle granicy } \\
\text { stosowania tych pojęć; } \\
\text { 3. Wreszcie, w związku z odpowiednimi czę́s- } \\
\text { ciami kursu, zwłaszcza nauki o ciele ludzkim, } \\
\text { udzielenie uczniom podstawowych wiadomo- } \\
\text { ści z higieny. }\end{array}$ \\
\hline
\end{tabular}

Źródło: Program gimnazjum państwowego, wydzial humanistyczny, Warszawa 1922 oraz Program gimnazjum państwowego, wydziat matematyczno-przyrodniczy, Warszawa 1922.

Agnieszka Watega

Toruń

\title{
Wanda Szuman (1890 - 1994) - zarys życia i działalności pedagogicznej
}

\section{Uwagi wstępne}

Wanda Szuman była pedagogiem, psychologiem oraz opiekunem ludzi kalekich. Pracowała także niezwykle aktywnie $w$ różnorakich organizacjach społecznych i pedagogicznych. Córka znanego lekarza Leona Szumana, siostra wybitnego psychologa i wykładowcy Uniwersytetu Jagiellońskiego Stefana Szumana, całym swoim działaniem społeczno-pedagogicznym dopisała kolejną wspaniałą kartę do dziejów rodziny. Podsumowanie tego niezwykle aktywnego życia zamknęła w jednym prostym 
zdaniu: „Nie dokonałam żadnych nadzwyczajnych rzeczy - ja tylko nie zmarnowałam życia”. Ci, którzy ja znali wspominaja ja niezwykle ciepło i ze wszystkich tych wypowiedzi przebija jedna przewodnia myśl, którą najlepiej ujął jej wieloletni współpracownik profesor Andrzej Wojciechowski: „Pani Wanda, cichutka, skromniutka. Nie było widać jej siły, siła do niej wówczas nie pasowała. A ona chyba nie przejmowała się, że coś jej nie wychodziło, po prostu wiedziała, że sprawy potoczą się tak, jak maja się potoczyć. (...) Nie ważyła zadań, które ma podejmować. Ona nie pytała, czy to czego się podejmie będzie fura kamieni czy furą siana. To była rzecz, którą trzeba będzie zrobić. „Bo mnie tam potrzeba " - mawiała"!. A potrzebna była w wielu przedsięwzięciach społeczno-oświatowych, począwszy od schyłkowego okresu panowania władz pruskich aż po czasy współczesne.

\section{2. Życie i działalność Wandy Szuman do 1939 roku}

Urodziła się 3 kwietnia 1890 roku jako piąte z siedmiorga dzieci Leona i Eugenii z Gumpertów. Jej ojciec odnosił już wówczas znaczne sukcesy zawodowe a matka była znaną działaczką społeczna. W domu panowały nastroje patriotyczne i postawy filantropijne. Jednocześnie władze pruskie kontynuowały politykę germanizacyjna zakazując w 1887 roku nauki języka polskiego w szkołach Torunia. W czasie gdy Wanda pobierała naukę w zakresie elementarnym (lata 1897-1907), groziło jej wyrzucenie ze szkoły za używanie języka polskiego w czasie pauzy. Później, jak wiele zamożniejszych dziewcząt, wyjechała na teren zaboru austriackiego, gdzie prowadzono naukę języka polskiego. Kształciła się w Krakowie i w Gimnazjum Sióstr Sacrè-Coeur we Lwowie. W 1911 roku ukończyła Seminarium dla Nauczycieli Szkół Ludowych w Krakowie. Już wówczas podjęła pierwsze działania w dziedzinie oświaty - prowadziła tajne nauczanie języka polskiego i religii w domu rodzinnym j w salkach przy kościele św. Jakuba w Toruniu².

Wanda Szuman rozpoczęla swoja szerszą działalność na polu oświatowym w 1914 roku, gdy razem z Heleną Steinbornową założyła „Wełniankę" - polska organizację samokształceniowa dla dziewczat ${ }^{3}$. Był to odpowiednik, popularnych $w$ czasie wojny, niemieckich Strickkranzchen, czyli zespołów kobiecych zajmujących się wyrobem rękawiczek, szalików i skarpetek dla żołnierzy na froncie. Jednak cele działalności toruńskiej „Wełnianki” były znacznie szersze, prowadzono tam naukę języka i historii polskiej oraz kultywowano na zebraniach polską pieśń narodową i patriotyczną. Wystawiano także przedstawienia teatralne i organizowano zabawy ludowe ${ }^{4}$.

Zaangażowanie $w$ działalność „Wełnianki” dało jej dobre przygotowanie do dalszej pracy społecznej i oświatowej w trudnym okresie przed ostatecznym odzyskaniem przez Polskę niepodległości. W ostatnim roku wojny Wanda Szuman coraz więcej czasu poświęcała idei szkolnictwa polskiego na Pomorzu, czemu sprzyjało rozluźnienie nacisku germanizacyjnego spowodowane nieuchronnie zbliżająca się klęską Niemiec. W październiku 1918 roku weszła ona w skład zarządu filii Powszechnego Towarzystwa Pedagogicznego w Poznaniu. Po zakończeniu wojny i utworzeniu w Toruniu Polskiej Rady Ludowej (17 września 1918) została przewodniczaca Wydziału Szkolnego Rady. Później, po utworzeniu w Poznaniu Naczelnej Rady Ludowej, przewodniczyła powołanej przez nią Komisji Szkolnej na obwód Regencji Kwidzyńskiej. Wtedy to na święto pierwszego maja wydała w Toruniu swoja pracę „Komisja Edukacyjna pierwszym ministerstwem oświaty w Europie”. W ramach pracy Komisji Szkolnej ogłosiła akcję "Narodowego Dnia Pracy" na cele oświatowe, w wyniku czego zebrano fundusze, które pozwoliły na otwarcie 22 maja 1919 roku Seminarium Nauczycielskiego w Toruniu i podjęcie prac nad uporzadkowaniem całego systemu oświaty dorosłych ${ }^{5}$.

' A. Machowski, Wanda Szuman - anima candida, „Sługa” Pismo Alumnów Wyźszego Seminarium Duchownego w Toruniu, Boże Narodzenie 1997, s. 7.

2 B. Dokurno, C. Iwaniszewska, Kalendarium życia Wandy Szuman [w:] Wanda Szuman. Historia jednego zycia, praca zbiorowa pod red. Cz. Łapicza, Toruń 1996, s. 115.

${ }^{3}$ Ibidem (Helena z Kawczyńskich Steinbornowa [1875 - 1952] wraz z mężem dr med. Ottonem Steinbornem byli inicjatorami i współorganizatorami polskiego zycia kulturalnego na Pomorzu w latach 1916-1920).

${ }_{4}$ T. Zakrzewski, Życie polskie Torunia $w$ ostatnich latach zaboru pruskiego (1916-1920), Toruń 1985, s. 20.

s Idem, Szuman Wanda [w:] Toruński Słownik Biograficzny, t. II, s. 234. 
Otwarcie tego seminarium poprzedziły starania Wandy Szuman o przygotowanie kadr nauczycielskich dla powstających szkół polskich i powołanie w tym celu w Toruniu Komisji Maturalnej, której zadaniem było opracowanie programów nauczania j przygotowanie pierwszych nauczycieli, a w konsekwencji uruchomienie kursów nauczycielskich i seminarium ${ }^{6}$. W 1920 roku, ze względu na doświadczenie zdobyte $w$ tym zakresie została wybrana wizytatorka komisji (kuratorium) na województwo pomorskie i prowadziła Referat Dokształcania dla Nauczycieli Pomocniczych ${ }^{7}$.

Nie sposób nie docenić ogromu pracy wykonanego przez Komisję Szkolna na obwód Regencji Kwidzyńskiej. Zbierała ona statystyki wszystkich dzieci, nauczycieli i szkół na swoim terenie, dostarczała podręczniki nauczycielom i osobom kwalifikującym się do uczenia, udzielała wszelakich informacji z zakresu szkolnictwa, wyszukiwała nauczycieli rozproszonych za granica, zakładała kursy dla dorosłych oraz opracowywała plany nauki na pierwszy rok nauki w Prusach Królewskich. Członkowie Komisji zachęcali nauczycieli do pracy dla nauki polskiej, a przede wszystkim do dopilnowania przyznanych Polakom praw nauki polskiej w szkołach, w dozwolonym przez pruskie ministerstwo ograniczonym zakresie trzech godzin tygodniowo dla języka polskiego i czterech godzin dla religii. Członkowie Komisji podejmowali osobiście wyjazdy przez kordony Grenzschutzu w celu zdobycia książek, co wówczas stanowiło poważny problem. W wyniku tych działań biblioteka Komisji Szkolnej liczyła w 1919 roku około 400 tomów, podczas gdy księgamie w Prusach Królewskich nie zdołały $w$ tym czasie sprowadzić żadnych ksiazzek ${ }^{8}$.

Rok 1919 to dla Wandy Szuman nie tylko działalność w Komisji, w tym samym czasie zaangażowała się ona w akcję "Ratujcie Dzieci”, zainicjowaną w Warszawie przez znaczące osobistości II Rzeczypospolitej, którym przewodniczyła Helena Paderewska. Została członkinią Rady Dzielnicowej tej akcji (lata 1919-1920) oraz podjęla liczne starania w celu poprawy losu dzieci z Torunia $\mathrm{i}$ okolicy. Zadania te realizowała w ścisłym współdziałaniu ze zorganizowanym wspólnie z bratem, księdzem Henrykiem Szumanem, Pomorskim Towarzystwem Opieki nad Dziećmi. Stawiało ono sobie za cel roztoczenie opieki nad dziećmi osieroconymi i opuszczonymi oraz kształcenie kadr posiadających przygotowanie w zakresie pracy opiekuńczo-wychowawczej, dla tak zwanych ochronek. O skuteczności pracy Towarzystwa świadczy chociażby to, że w krótkim czasie wysłało ono kilkaset dzieci, głównie ze środowisk zaniedbanych, na letni wypoczynek na wieś oraz nad morze9. Wanda Szuman wchodziła w skład zarządu tego Towarzystwa i chociaż stawiało ono sobie za główny cel ochronę dzieci i młodzieży oraz opiekę nad sierotami, to w swoim statucie wyróżniło następujące priorytetowe formy działalności:

- organizowanie kolonii letnich dla dzieci miejskich;

- umieszczanie sierot i dzieci opuszczonych w zakładach i rodzinach chrześcijańskich;

- otwieranie i kierowanie domami sierocymi, żłobkami, ochronkami i tym podobnymi zakładami;

- roztoczenie opieki nad niemowlętami i dziećmi wanunkowo zasądzonymi;

- wyszukiwanie odpowiednich osób, chcạcych się podjąć prawnej opieki nad sierotami i dziećmi;

- urzadzanie publicznych wykładów i udzielanie wszelkich informacji o wyżej wymienionych sprawach $^{10}$.

Towarzystwo działało bardzo prężnie i w 1921 roku miało pod swoją opieką następujące zakłady:

- Kuchnię Mleczną, otwarta codziennie w godzinach od 11-tej do 15-tej;

- Poradnię dla Matek z dyżurami lekarza powiatowego, otwarta co czwartek od godziny 16-tej do 19-tej;

- Schronisko Sieroce im. gen. J. Hallera;

- Stację Przejściowa dla Dzieci;

6 J.A. Malinowski, Wanda Szuman. Honorowy Obywatel Torunia, „Pomorze i Kujawy” 1999, nr 6, s. 24 - 25.

7 A. Goszczyńska, Niezwykle życie, niezwykli podopieczni, „Swiat Ciszy” 1990, nг 4, s. 4.

${ }^{8}$ Biblioteka Główna UMK - Dzial Rękopisów (dalej cyt. BG UMK - DR), sygn. 1249, Wanda Szuman Historia, korespondencja 1918-1966, Odpis referatu Wandy Szuman z dnia 8 września 1919 roku.

${ }^{9}$ J.A. Malinowski, op. cit., s. 24.

${ }^{10}$ Archiwum Państwowe Toruń (dalej cyt. APT), Polskie organizacje spoleczne i zawodowe, Grupa zespolów lat 1815-1949, Pomorskie Towarzystwo Opieki nad dziećmi, sygn. 1, Regulaminy Towarzystwa i internatu 1921. 
- Kolonię Lecznicza dla Dzieci im. błogosławionego Andrzeja Boboli w Gdyni, która przyjmowała rocznie, w ciagu czterech sezonów 200 dzieci ${ }^{1 !}$.

W 1931 roku, ze względu na inne obowiazzki zawodowe Wanda Szuman nie weszła już w skład zarzadu Towarzystwa, ale nadal była jego członkiem i współpracownikiem, a po II wojnie światowej pełniła $\mathrm{w}$ nim obowiązki sekretarki ${ }^{12}$.

Ważnym aspektem działalności Wandy Szuman w tamtym okresie było również Pomorskie Koło Panien. Organizacja ta rozwinęła się z „Wełnianki”, działała od 15 sierpnia 1918 roku i stawiała sobie za cel samokształcenie swoich członkiń. Od paździemika 1918 roku rozszerzono jej zadania również na kształcenie osób niezrzeszonych. Do 1919 roku prowadzono kurs dla kierowniczek ognisk dziecięcych i wyszukiwano kandydatki na polskie urzędniczki i nauczycielki. Urządzano również kursy samokształceniowe dla różnych organizacji i stowarzyszeń, a każda z członkiń miała obowiązek opiekowania się kompletem dzieci polskich ${ }^{13}$. Bodźcem do utworzenia tej organizacji był list z propozycja współpracy na polu społeczno-oświatowym, który Wanda Szuman otrzymała w listopadzie 1917 roku od Władysławy Wolszlegierówny. Obie panie nawiąały interesujaca korespondencję dotycząca kwestii programu, statutu, siedziby organizacji oraz właściwego jej przedstawienia policji, gdyż wciaż jeszcze musiały wówczas brać pod uwage organy administracji zaborcy pruskiego ${ }^{14}$. Wanda Szuman nawiązała kontakty z poznańskim Kołem Panien, aby zyskać orientację w formach i zakresie jego działalności. Projekt koła toruńskiego był szerszy od poznańskiego, gdyż zakładał zarówno samokształcenie, jak i pracę społeczna, podczas gdy w Poznaniu każdą z tych dziedzin zajmowała się odrębna organizacja. Postanowiono jednak nawiazać bliższa współpracę i przesyłać sobie nawzajem sprawozdania z zebrań, z działalności itp. ${ }^{15}$

Grunt pod działalność stowarzyszenia został przygotowany $\mathrm{i}$ na inauguracyjnym zjeździe panien w Gdańsku 15 lipca 1918 roku przyjęto nazwę Koło Panien na Prusy Królewskie oraz siedzibę w Chełmży, natomiast w październiku 1918 roku zmieniono siedzibę na Gdańsk. Na to pierwsze spotkanie przybyło ponad pięćdziesiat panien, Wanda Szuman wyglosiła wówczas referat o tragizmie w życiu Żółkiewskiego. Na zebraniu tym ustalono, że Koło ma na celu samokształcenie, z ta jednak charakterystyczną różnica wobec koła poznańskiego, że w tutejszym Kole moga działać nie tylko panny ze wsi, ale również te mieszkające $w$ mieście ${ }^{16}$. Koło rozpoczęło swoja oficjalną działalność, na jego przewodniczącą wybrano Władysławę Wolszlegierównę; Wanda Szuman pełnila obowiązi radnej. Była ona czynna uczestniczka i pomysłodawczynia wielu przedsięwzięć stowarzyszenia. Zwracała bardzo dużą uwagę na pracę społeczną w ramach Koła, dażyła do utworzenia w każdym okręgu kółek pod różnymi nazwami. Poszczególni członkowie każdego kółka mieli należeć przynajmniej do jeszcze jednego towarzystwa ludowego, na przykład do Bractwa Dzieci lub Dziewcząt, do Koła Śpiewaczego, Kółek Rolniczych itp. Mieli tam za zadanie udzielanie pomocy przy pracach biurowych i nauczaniu oraz ożywianie ruchu poprzez prowadzenie wykładów, organizowanie przedstawień, ćwiczenie śpiewów oraz pomoc przy tworzeniu nowych stowarzyszeń ${ }^{17}$.

Wraz z odzyskaniem przez Polskę niepodległości zmianie uległy realia pracy Koła, nie było już powodu dla ukrywania prawdziwych celów działalności stowarzyszenia, czyli, jak głosił statut z 1920 roku: „organizowania wśród panien województwa pomorskiego stałej pożytecznej pracy oraz stworzenie stałego kontaktu między całym społeczeństwem przez oświecanie i pouczanie drugich (kursy wieczorne, przedstawienia ludowe, zdobnictwo swojskie)". Zmianie uległa także nazwa stowarzyszenia

\footnotetext{
"Ibidem.

12 Ibidem, sygn. 2, Sprawy ogólno-administracyjne 1919-1939.

${ }_{13}$ B. Dokurno, C. Iwaniszewska, op. cit., s. 116.

14 APT, Polskie organizacje..., Pomorskie Koło Panien, sygn. 1, Sprawy ogólno-administracyjne. Korespondencja dotyczaca założenia 1917-1918, oryginał listu W. Wolszlegierówny do W. Szuman z dnia 26 listopada 1917 roku.

${ }^{15}$ Ibidem, oryginał listu T. Konińskiej do W. Szuman z dnia 22 maja 1918 roku.

16 APT, Poiskie organizacje..., Pomorskie Kolo Panien, sygn. 7, Zjazd Kola Panien w Gdańsku.

17 APT, Polskie organizacje..., Pomorskie Kolo Panien, sygn. 2, Ustawy Koła Panien z 1919 roku, odręczna notatka W. Szuman o pracy spolecznej w ramach Koła.
} 
z Koła Panien na Prusy Królewskie na Pomorskie Koło Panien oraz siedziba z Gdańska na miasta wojewódzkie ${ }^{18}$.

Dopiero po powrocie Pomorza do Polski w 1920 roku Wanda Szuman znalazła czas na bardziej usystematyzowany dalszy rozwój naukowy. W latach 1921-1923 studiowała w Państwowym Instytucie Pedagogicznym w Warszawie, gdzie spotkała wybitnych pedagogów specjalnych - Marię Grzegorzewską i Józefę Joteyko oraz Janusza Korczaka. Kilka lat później, w 1926 roku właśnie u tego znanego już wówczas w Polsce pedagoga doskonaliła swoje umiejętności badawcze odbywając staż w prowadzonej przez niego placówce opiekuńczo-wychowawczej ${ }^{19}$. W Instytucie Pedagogicznym przygotowała pracę dyplomowa na temat opieki nad sierotami - był to wówczas w okresie powojennym ważny problem społeczny. W międzyczasie otrzymała roczne ministerialne stypendium zagraniczne i w 1925 roku wyjechala poznawać systemy opieki nad dziećmi we Francji, Belgii i Anglii. Ponieważ szczególnie interesował ja problem sieroctwa społecznego otrzymała zadanie opracowania systemu opieki nad sierotami w Polsce. Przeprowadziła wówczas szereg unikalnych prac badawczych nad sieroctwem i różnicami w rozwoju mowy u dzieci wychowywanych w domach rodzinnych i w placówkach wychowawczych ${ }^{20}$. Te badania skłoniły ja do zorganizowania, opartego częściowo na systemie angielskim, Komitetu Umieszczania Sierot w Rodzinach; napisała też pracę „Charakterystyka sierocińców nowego typu”. Po powrocie do kraju kontynuowala prace w tym kierunku prowadzac badania w zakładach dla sierot w Domu im. Księdza Baudoina w Warszawie i u księży Michaelitów w Pawlikowicach. W Zakładzie im. Księdza Baudoina przebywało wtedy około 1000 dzieci poniżej czwartego roku życia ${ }^{21}$. Tak później wspominała swoja pracę w tamtym zakładzie:

„Nie sposób wymazać z pamięci obrazu tysiąca dzieci, w jednakowych szarych sukienkach, tysiaca par oczu jednakowo smutnych. Tysiac dzieci do lat trzech w jednym budynku"22.

„Do tego zakładu matki przynosiły niechciane dzieci, w drzwiach była obrotowa deska i po drugiej stronie siostry odbierały podrzutka"23.

Jej badania o wiele lat wyprzedziły późniejsze prace podejmowane przez wielu autorów nad problemem tak zwanej choroby sierocej u dzieci wychowywanych od najmłodszych lat w różnorakich zakładach poza rodziną. $\mathrm{Z}$ zakresu tej problematyki prowadzila także wykłady na wielu kursach państwowych i prywatnych w Warszawie i w Poznaniu, poświęciła jej także około piętnastu artykułów, opublikowanych $w$ kilku pracach zbiorowych i w czasopismach ${ }^{24}$.

Oto kilka z nich:

- Wychowanie dzieci przestepczych w Belgii, „Szkoła Specjalna”, Warszawa 1925, nr 4;

- Wychowanie sierot w Anglii, „Opieka nad Dzieckiem”, Warszawa 1926, nr 6-7;

- Belgijskie zakłady rodzinne dla sierot, „Opieka nad Dzieckiem”, Warszawa 1927, nr 2;

- Jak dowieść rzeczywistej wartości zakładu wychowawczego, „Opieka nad Dzieckiem”, Warszawa 1928, nr 5;

- Szkoty nowego typu a zaktady dla sierot, „Wychowawca”, Warszawa 1928, nr 5;

- Trudności w wychowaniu sierot, „Opieka nad Dzieckiem”, Warszawa 1928, nr 3;

- Wychowanie dziecka i szczęście dziecka, „Opieka nad Dzieckiem”, Warszawa 1930, nr 3;

- Rodzice chrzestni dla sierot, „Wychowawca”, Warszawa 1932, $\operatorname{nr} 2^{25}$.

\footnotetext{
${ }^{18}$ APT, Polskie organizacje..., Pomorskie Koło Panien, sygn. 3, Protokoły zebrań zarządu, protokół z zebrania PKP z dnia 2 lipca 1920 roku.

19 J.A. Malinowski, op. cit., s. 25.

20 L. Ścibor-Rylski, Oddana ludziom, któnych pokrzywdzil los, „Nowości” 1980, nr 73, s. 4.

${ }^{21}$ Cz. Kosakowski, Zastuzeni dla pedagogiki specjalnej, „Szkoła Specjalna” 1995, nr 3, s. 170.

22 B. Dzięgielewska, Niestrudzona, „Zwierciadło" 1982, nг 28 (1309), s. 6.

${ }_{23}^{3}$ L. Ścibor-Rylski, Ulica Szumanów, „Fakty” Tygodnik Społeczno-Kulturalny 1980, nг 16, s. 6.

${ }^{24} \mathrm{Cz}$. Kosakowski, op. cit., s. 171 .

${ }^{25}$ Idem, Wanda Szuman w stuzbie ludziom [w:] Wanda Szuman w stulecie urodzin, praca zbiorowa pod red. J. Huppentbal, Toruń 1991, s. 28.
} 
Swoje zainteresowania problematyką społeczną kontynuowała w następnych latach, będąc do 1932 roku wykładowca i organizatorem pierwszych w Polsce Państwowych Kursów Służby Społecznej w Warszawie ${ }^{26}$. Lata 1933-1939 wypełniła jej praca oświatowa w Poznaniu, objęła tam kierownictwo katolickiego Seminarium dla Wychowawczyń Przedszkoli oraz Katolickiego Studium Społecznego, które było instytucja przygotowująca wychowawczynie do opieki nad dziećmi ${ }^{27}$. W tym okresie interesowała się szczególnie sprawami opracowania zestawu zabaw i gier dla dzieci. Wydała wówczas dwie książeczki „Zabawy z najmłodszymi dziećmi” (Warszawa 1935) oraz „Rysowane wierszyki” (Poznań 1937), które cieszyły się olbrzymim powodzeniem. Niedawno na rynku księgarskim pojawiły się ich nowe wydania, co świadczy najlepiej o tym, że propozycje Wandy Szuman w tym zakresie nadal sa aktualne.

\section{Lata wojny i okupacji, działalność w Radzie Głównej Opiekuńczej}

Kolejny etap działalności Wandy Szuman na polu oświaty przypadł na lata II wojny światowej. Okres ten spędziła ona początkowo w Humniskach pod Sanokiem, przesiedlona tam przez Niemców, oficjalnie jako nauczycielka szkoły powszechnej, potajemnie zaś prowadziła nauczanie języka i historii polskiej. Pod koniec 1942 roku przeniosła się do Radomia, gdzie aktywnie działała na rzecz dzieci w Polskim Komitecie Opiekuńczym przy Radzie Głównej Opiekuńczej, pełniąc tam funkcję referentki do spraw opieki nad dziećmi oraz działajac $w$ referacie opieki nad więźniami ${ }^{28}$. Zadaniem Sekcji Opieki nad Dziećmi i Młodzieża była opieka moralna i materialna nad dziećmi do lat szesnastu, a w szczególności sprawowanie nad nimi opieki całkowitej lub częściowej i udzielanie im różnorakiej pomocy w kuchniach dziecięcych, nadzorowanych przez siebie żłobkach, ogniskach i internatach, bursach oraz na prowadzonych półkoloniach. Ponadto zajmowano się wówczas urządzaniem systemu sąsiedzkiej opieki nad dziećmi w zakresie ich dożywiania i prowadzono akcję umieszczania dzieci w rodzinach zastępczych. Otaczano opieką domową sieroty, rodziny bez żywicieli, szczególnie rodziny nieobecnych żołnierzy, inwalidów i ciężko poszkodowanych przez skutki wojny, dzieci pozbawione czasowo opieki na skutek aresztowań, wywożenia na roboty itp., dzieci chore na gruźlicę, bezdomne i zajmujace się włóczęgostwem, które wymagały pobytu w specjalnych zakładach wychowawczych, o ile nie miały wkrótce wejść na drogę przestępczości ${ }^{29}$.

Wanda Szuman opiekowała się wówczas siedmioma przedszkolami, zorganizowała świetlicę dla chłopców, stworzyła dwa stałe sierocińce, czuwała nad sześćdziesięcioma kuchniami ludowymi i specjalnymi punktami dożywiania dzieci z miasta i powiatu. Zajmowała się także wysiedleńcami i więźniami, organizowała akcje ich dożywiania, wysyłała paczki do obozów koncentracyjnych, zainicjowała też specjalną opiekę indywidualną nad dziećmi osób uwięzionych ${ }^{30}$.

Latem 1943 roku współorganizowała akcję kolonijna, w ramach której odbyło się siedem pólkolonii z których skorzystało prawie tysiąc dzieci. Na temat swojej ówczesnej działalności w zakresie opieki nad więźniami tak pisała w liście do brata Stefana w lutym 1943 roku: „Komitet żywi ludzi w obozie przeznaczonym na roboty do Niemiec. W największe mrozy wożę kawę, zupę i tym podobne o jakieś trzy kilometry stąd, a że ja umiem po niemiecku, więc największa praca mnie przypadła. Teraz znowu żywimy ludzi złapanych do Arbeitsamtu. Obecną pracę lubię, wolno nam uświadamiać rodziny, by przyniosły paczki, a także wolno nam wskazywać matki małych dzieci i te uzyskuja zwolnienie po przedstawieniu właściwych dokumentów"31.

${ }^{26}$ T. Zakrzewski, Szuman Wanda..., s. 235.

27 J.A. Malinowski, op. cit., s. 25.

${ }^{28} \mathrm{Cz}$. Kosakowski, op. cit., s. 171 .

29 BG UMK- DR, Spuścizna Rękopiśmienna W. Szuman, sygn. 2355/III, Materiały z okresu II wojny światowej, Regulaminy Sekcji Opieki nad Dziećmi (maszynopisy).

${ }^{30}$ B. Dokurno, C. Iwaniszewska, op. cit., s. 118.

31 G. Czyżewiczowa, Opowiadania rodzinne. Wybór listów i pamiętników rodzinnych, t. III, Stefan i Zofia Szumanowie. Okupacja i późne lata, s. 61. (BG UMK - DR) 


\section{Główne kierunki działalności w okresie powojennym}

Po wojnie Wanda Szuman wróciła do Torunia i za zgoda reszty rodziny przekazala na cele oświatowe budynek, w którym mieściła się dawniej klinika lecznicza jej ojca. Zorganizowała w nim Liceum dla Wychowawczyń Przedszkoli i została jego pierwsza dyrektorka ${ }^{32}$. W 1949 roku została jednak z dnia na dzień pozbawiona pracy i odwołana ze stanowiska, o czym dowiedziała się, jak to było wówczas często stosowane, $z$ prasy. Lata powojenne nie sprzyjały osobom, które tak jak ona zajmowały konsekwentne $i$ jasno określone pozytywne postawy wobec religii ${ }^{33}$. Po odwolaniu Wanda Szuman otrzymała półroczny płatny urlop w czasie którego uzupełniła swoje wykształcenie w Instytucie Higieny Psychicznej w Warszawie ${ }^{34}$. Prowadziła też wówczas badania nad dziećmi z różnymi odchyleniami rozwojowymi ${ }^{35}$. Sytuacja w kraju ulegała jednak stopniowym zmianom i w roku 1958 sprawa zwolnienia Wandy Szuman ponownie zainteresowały się władze. Oto fragment uzasadnienia decyzji podjętej przez Wydział Oświaty Wojewódzkiej Rady Narodowej w Toruniu z dnia 10 lutego 1958 roku: „Komisja uznała, że przeniesienie w stan nieczynny na podstawie artykułu 53 ustawy $z$ dnia 1 lipca 1946 roku z podkreśleniem »okoliczności nie pozwalających ze względu na dobro służby na dalsze zatrudnianie Obywatelki na odpowiadającej stanowisku służbowemu Obywatelki posadzie« jest krzywdzace moralnie. Krzywda ta staje się tym większa, jeżeli weźmie się pod uwagę wkład pracy Obywatelki dla polskości na terenie byłego zaboru pruskiego przed 1918 rokiem. Komisja w pełni rehabilituje Obywatelkę i wnosi o naliczenie jej lat pracy od 1 IX 1952 do 31 XII 1956 oraz przyznanie jej emerytury według obowiazujących przepisów"36.

Jednak ta sprawa nie zahamowała działalności oświatowej i pedagogicznej Wandy Szuman. Po zwolnieniu w 1949 roku z funkcji dyrektorki pracowała jeszcze do 1952 roku jako psycholog w Pogotowiu Opiekuńczym w Toruniu oraz jako instruktor zająć terapeutycznych w zakładach Towarzystwa Prewentoriów i Domów Dziecięcych. Dopiero w 1952 roku przeszła na emeryturę i wówczas rozpoczęła szereg doniosłych badań naukowych ${ }^{37}$. Badania prowadziła między innymi w sanatoriach dla Dzieci z Gruźlica Kostną Stawów i w szpitalach dziecięcych, zajmowała się również psychoterapia w zakładach dla dzieci niewidomych ${ }^{38}$.

Dla Polskiej Akademii Nauk badała rozwój dwóch chlopców wychowywanych do piątego roku życia w skrajnej izolacji, odnalezionych w 1954 roku we Włocławku. Pomagała w ich wychowaniu i rehabilitacji, kontakt z nimi utrzymywała do końca swojego życia, działała też aktywnie na rzecz zapobiegania podobnym przypadkom, gdyż sprawa tych dwóch chłopców nie była niestety wówczas odosobniona $a^{39}$. Wanda Szuman zajmowała się nimi od momentu, gdy na mocy postanowienia Sądu Powiatowego chłopcy, Boleś w wieku pięciu lat i sześciu miesięcy i Staś w wieku czterech lat i trzech miesięcy, zostali zabrani od rodziców i przewiezieni do Okręgowego Pogotowia Opiekuńczego w Toruniu w dniu 27 października 1954 roku. Izolacja dzieci polegała na stałym trzymaniu ich w zamkniętym pokoju z zasłoniętymi oknami, chłopcy w ogóle nie mogli wychodzić poza obręb tego ciemnego i niesłychanie brudnego pomieszczenia. Ich matka twierdziła, że „dzieci mogłyby umrzeć, gdyby zobaczyły jakiegoś człowieka, bo są nerwowo chorzy i boją się ludzi". Rodzice ich nie pracowali, mieszkali w fatalnych warunkach, całymi dniami zajmowali się żebractwem i pozostawiali dzieci samym sobie. W wyniku tak niesprzyjajacych warunków rozwojowych stan chłopców był fatalny, obaj mieli silną krzywicę i niemal zupełny brak uzębienia, nie potrafili chodzić ani mówić.

${ }^{32}$ L. Ścibor-Rylski, Oddana ludziom..., s. 5.

${ }_{33}$ M. Zacharski, Zýc dla innych, „Centrum” 1997, nr 6, s. 3.

${ }^{34} \mathrm{Cz}$. Kosakowski, op. cit., s. 171 .

35 APT, Archiwum fotograficzne Alojzego Czameckiego, sygn. 115, Wanda Szuman, Życiorys W. Szuman spisany przez nia sama.

${ }^{36}$ Ibidem, Własnoręczny odpis W. Szuman dokonany dnia 20 marca 1974 roku.

${ }_{77}$ T. Zakrzewski, Szuman Wanda..., s. 235.

${ }^{38}$ APT, Archiwum fotograficzne...., Życiorys...

39 BG UMK - DR, Spuścizna Rękopiśmienna..., sygn. 2377/III, Przebieg badań nad chłopcami wychowywanymi w skrajnej izolacji. 
W ciągu dwóch miesięcy pobytu w Toruniu nauczyli się spać w łóźkach, siedzieć, chodzić i jeść normalne posiłki, gdyż dotąd matka karmiła ich butelka. Do końca 1955 roku chłopcy przebywali w zakładzie prowadzonym przez siostry zakonne w Chełmnie, później Wanda Szuman zorganizowała im pobyt w Domu Zdrowia w Ciechocinku oraz naukę w zawodowej szkole ogrodniczej przy szkole specjalnej w Grudziadzu. Sama wybrała dla nich wychowawczynię, byłą prywatna nauczycielkę, Eleonorę Wiwatowska z Chełmna ${ }^{40}$.

Przez pierwsze dwa miesiace ich pobytu w pogotowiu Wanda Szuman spędzała $z$ nimi przeciętnie sześć do siedmiu godzin na wywiadach, obserwacji i nauce tych dzieci a drugie tyle czasu przeznaczała na porzadkowanie i spisywanie zebranych materialów. Później zorganizowała im systematyczną $\mathrm{i}$ indywidualną naukę mówienia. Przeprowadziła na własny koszt $\mathrm{w}$ Studiu Polskiego Radia zradiofonizowanie wydawanych przez nich dźwięków i zabiegała o sfilmowanie ich przez Kronikę Filmowa, z tym jednak zastrzeżeniem, że film będzie wykorzystywany wyłączie w celach naukowych ${ }^{4}$. Prace te zabierały tyle czasu, ze zrezygnowała $\mathrm{z}$ innych płatnych prac i lekcji prywatnych, by jak najlepiej zając się chłopcami. Była nawet zmuszona czasowo wywieźć ich poza Toruń, gdyż istniały uzasadnione podstawy do podejrzewania ich rodziców o dokonanie próby porwania dzieci ${ }^{42}$. W sprawic tego przypadku nawiązała korespondencję z profesorem uniwersytetu w Moskwie, J. Galferinem, który sam miał w tej dziedzinie spore doświadczenie. W 1964 roku pisała do niego: „Publikowałam dotad niewiele na temat tych chłopców. Obawiam się, żeby nie stali się przedmiotem ogólnej ciekawości zabijającej ambicje i pozwalającej szukać znaczenia przypadkowego. Zreszta jak już zaznaczyłam sa oni bardzo wrażliwi na pytania o przeszłość i rodziców. Głównym moim zadaniem jest w ostatnich latach szerzenie racjonalnych zasad rehabilitacji osób niewidomych. Jednak jako prawny opiekun tych dzieci czuję się za nich nadal odpowiedzialna i staram się mieć wpływ na ich wychowanie na ludzi i poprawę ich mowy, w tym celu zabrałam ich niedawno na dwa tygodnie do Torunia, aby mogli chodzić tutaj na specjalne lekcje mowy"43.

Tak jak pisała w liście do profesora Galferina, od 1956 roku zajmowała się problematyką tyflologiczna. Z ramienia Sekcji Defektologii Państwowego Instytutu Pedagogiki Specjalnej rozpoczęła wówczas badania nad rysunkiem dzieci niewidomych w Ośrodku Szkolno-Wychowawczym w Bydgoszczy. W zakładzie tym uczyły się i mieszkały dzieci w wieku szkoły podstawowej i trzyletniej szkoły zawodowej. Efektem tych badań była jej książka „O dostępności rysunku dla dzieci niewidomych" ${ }^{44}$. Zainteresowana ta problematyką kontynuowała badania w 1957 roku w Laskach pod Warszawa oraz w Owińskach w Państwowym Zakładzie Dzieci Niewidomych ${ }^{45}$. W wyniku tych badań w 1959 roku zorganizowała pierwsza w Polsce Poradnię dla Rodziców Dzieci Niewidomych w Bydgoszczy. Już w 1958 roku Wanda Szuman nakreśliła następujące kjerunki poradnictwa dla rodziców dzieci niewidomych:

- dla dzieci pozostających poza zakładem, począwszy od okresu niemowlęctwa,

- dla dzieci będacych już w specjalistycznym zakładzie w Bydgoszczy.

Uważała, że niezbędne jest rozwinięcie szerokiej akcji propagandowej poprzez radio, prasę, różnorakie broszury wysyłane do placówek służby zdrowia, lecznic okulistycznych, związków niewidomych oraz placówek oświatowych na terenach, z których pochodzą przebywające w bydgoskim ośrodku dzieci ${ }^{46}$. Po uzyskaniu zgody kuratorium oświaty ułożyła szczegółowy program pracy poradni dla rodziców dzieci niewidomych, który obejmował następujące problemy:

\footnotetext{
${ }^{40}$ Ibidem, Notatki W. Szuman.

4) Ibidem, sygn. 2362/III, Polska Akademia Nauk, Brudnopis listu W. Szuman do PAN z kwietnia 1955 roku.

42 Ibidem, Brudnopis listu W. Szuman do PAN z 12 lipca 1956 roku.

${ }^{43}$ Ibidem, sygn. 2339/III, Korespondencja dotycząca braci W.

44 Ibidem, sygn. 2326/III, Zakład dla Niewidomych w Bydgoszczy, Notatki W. Szuman.

45 Ibidem, sygn. 2327/III, Laski - materiały z badań oraz 2328/III, Owińska - Państwowy Zakład Dzieci Niewidomych.

${ }_{46}$ Ibidem, sygn. 2330/III, Poradnictwo dla rodziców, Protokół 2 zebrania w sprawie powołania poradni dla rodziców w dniu 24 listopada 1958 roku.
} 
- propagowanie poradnictwa;

- gromadzenie ewidencji dzieci niewidomych, począwszy od niemowlat;

- dostarczanie instrukcji rodzicom dzieci niewidomych oraz zainteresowanym tym problemem organom urzędowym i społecznym;

- udzielanie bezpośrednich wskazówek rodzicom dzieci niewidomych w siedzibie poradni, dwa razy w miesiacu $w$ soboty, między 10-ta a 14-ta:

- wyjazdy w teren w szczególnie ważnych i ciężkich przypadkach;

- przesyłanje opiekunom dzieci niewidomych specjalnych ulotek ze wskazówkami i utrzymywanie z nimi stałego kontaktu doradczego ${ }^{47}$.

W Polsce nie było wówczas ewidencji dzieci niewidomych ani prawnego obowiązku posyłania ich do szkoły. Ilość dzieci niewidomych nie była bowiem aż tak liczna - około półtora tysiąca na cała Polskę, przypadało więc po kilkoro niewidomych dzieci na powiat. Ale właśnie ze względu na to Wanda Szuman uważała kwestię poradnictwa dla rodziców tych dzieci za szczególnie potrzebna. Podejmowała liczne apelacje w celu poprawienia ich niekorzystnej sytuacji, między innymi interweniowała $w$ Ministerstwie Zdrowia i Opieki Społecznej w Warszawie. Wysuwała postulaty nałożenia obowiazku rejestrowania wszystkich dzieci niewidomych przez ośrodki służby zdrowia, szkolenia pielęgniarek i salowych w zakresie pracy z dziećmi niewidomymi oraz powołania specjalnych placówek leczniczych dla dzieci niewidomych obciazzonych dodatkowymi kalectwami ${ }^{48}$. Sama również podejmowała konkretne działania w celu pomocy osobom niewidomym organizujac między innymi w 1964 roku kursy rehabilitacyjne poświęcone nauce czarnego pisania dla niewidomych i ociemniałych ${ }^{49}$. W tym celu nawiązała kontakty z Polskim Zwiazkiem Niewidomych, działała aktywnie w jego sekcji kulturalno-oświatowej w okręgu bydgoskim oraz oceniała dla PZN wartość zagranicznych wydawnictw pod katem przydatności ich tłumaczenia na język brajla. W 1960 roku była inicjatorka zorganizowania wystawy osób niewidomych pracujacych przy wyrabianiu zabawek z drewna oraz wystawy $z$ okazji 80 -lecia urodzin głuchoniewidomej Heleny Keller. W tym samym roku zorganizowała w Toruniu kursy czytelnicze dla niewidomych oraz zamieściła na łamach „Gazety Toruńskiej” artykuły o konieczności życzliwości wobec niewidomych ${ }^{50}$. W 1961 roku zainicjowała duszpasterstwo dla niewidomych przy kościele księży Michaelitów w Toruniu przy ulicy Rybaki, które obejmowało comiesięczne msze święte, spotkania towarzyskie i oświatowe oraz wizyty duszpasterskie $w$ domach ${ }^{5 !}$. Problematyce tej poświęciła dwie swoje broszury wydane w Toruniu w latach 1961 - 1962: „O wychowaniu niewidomego dziecka” i „Dostępność rysunku dla dzieci niewidomych". Przekazywała w nich ważne przesłanie, iż dziecko niewidome, choć pozbawione niemal najważniejszego ze zmysłów może w wyniku wysiłku swoich opiekunów wyrosnać na człowieka zdrowego, inteligentnego i realizujacego swoje pasje. Jej koncepcje integracji środowisk dzieci chorych i zdrowych, aranżowanie sytuacji sprzyjających obalaniu uprzedzeń i nawiazaniu relacji akceptacji i zrozumienia sa do dnia dzisiejszego niezmiernie ważnym elementem rehabilitacji osób niepełnosprawnych.

W tym samym czasie zaangażowała się w inną formę działalności i 21 marca 1960 roku powołała w Toruniu Oddział Towarzystwa do Walki z Kalectwem. Z założenia miała to być wielka organizacja społeczno-naukowa, która miała pomagać $w$ organizowaniu i prowadzeniu różnych form walki z kalectwem oraz jego skutkami. Miała kształtować opinie i postawy szerokich rzesz społeczeństwa w stosunku do inwalidów, ich możliwości pracy $\mathrm{i}$ włączenia się $w$ normalne życie społeczne, zaznajamiać społeczeństwo z potrzebami inwalidów oraz rolą ich leczniczej i zawodowej rehabilitacji ${ }^{52}$. Towarzystwo organizowało akcje odczytowe, wydawnicze i prasowe, konferencje i zjazdy naukowe

\footnotetext{
${ }^{47}$ Ibidem, Program pracy poradni, Odręczna notatka W. Szuman.

48 Ibidem, Brudnopis listu W. Szuman do MZiOS z 1959 roku.

${ }^{49}$ Ibidem, sygn. 2326/1l, Zakład dla Niewidomych w Bydgoszczy, Notatki W. Szuman.

50 Ibidem.

${ }^{51}$ B. Dokumo, C. Iwaniszewska, op. cit., s. 120.

52 BG UMK - DR, Spuścizna.., sygn. 2360/III, Polskie Towarzystwo Walki z Kalectwem, Maszynopis referatu
} B. Pruskiego o konieczności powołania PTWzK z dnia 14 grudnia 1960 roku. 
oraz wystawy dotyczące problematyki walki z kalectwem. Urządzało kolonie dla dzieci kalekich, organizowało imprezy wspierające opiekę nad nimi, imprezy sportowe i usprawniajace, udzielało różnorakiej pomocy ich rodzicom. Ponadto zachęcało ludzi kalekich do wyjścia z izolacji społecznej, załatwiało $w$ ich imieniu uciążliwe sprawy urzędowe $\mathrm{i}$ współpracowało $\mathrm{z}$ innymi towarzystwami krajowymi i zagranicznymi ${ }^{53}$.

Kolejny ważny element pracy oświatowo-pedagogicznej Wandy Szuman stanowi jej wieloletnia wspólpraca z Uniwersytetem Mikołaja Kopernika w Toruniu. Prowadziła tam wykłady na Wydziale Humanistycznym i Sztuk Pięknych. W latach 1977-1981 organizowała w Bibliotece Głównej UMK wystawy prac niepełnosprawnych artystów, którymi się przez wiele lat opiekowała. Działalność ta rozpoczęła się zupełnie zresztą przypadkowo i to właśnie za sprawą zaangażowania się Wandy Szuman w realizację pomysłu zorganizowania takiego cyklu wystaw połączonego $\mathrm{z}$ kompletowaniem zbiorów o charakterze naukowym. Inwalidzi nazywali jạ swoim Mecenasem, ona zaś mówiła, że walczy dla nich nie o sławę, lecz o zapewnienie im takich warunków, które nadaja sens życiu. Szukała wszelkich możliwych okazji, by pomóc dzieciom i dorosłym w podjęciu wysiłków zmierzajacych do uzyskania przez nich pewnego możliwego w tych warunkach zakresu samodzielności ${ }^{54}$.

Zorganizowała wystawy następujących swoich podopiecznych:

- Jaroszka Ormowskiego, głuchoniemego od urodzenia wskutek ciężkiego zapalenia opon mózgowych, a $w$ wieku 10 lat pozbawionego, na skutek tragicznego wypadku, obu rąk powyżej tokci, malującego ustami obrazy olejne i wykonującego wypalanki w drewnie;

- Józefa Sikory z Bydgoszczy, całkowicie bezwładnego, który pierwsze swoje obrazy malował ustami w wieku 10 lat;

- Józefy Budzyń-Nowakowej, niewidomej rzeźbiarki;

- Ewy Panasewicz, wybitnie inteligentnej i zdolnej karykaturzystki z Bydgoszczy, przykutej na stałe do łóżka i władajacej tylko jedną ręka, chorujacej ponadto na epilepsję, która wykonywała rysunki piórkiem. W jej sprawie Wanda Szuman interweniowała u wicemarszałka Sejmu - profesor Haliny Skibniewskiej. Udało jej się załatwić dla niej całodzienną opiekę pielęgniarską oraz rentę rodzinną ${ }^{55}$.

Dzięki jej staraniom wielu uzdolnionych plastycznie niepełnosprawnych zaliczono do grona Międzynarodowego Związku Artystów Malujących Ustami lub Nogami, działającego w Vaduz, stolicy Księstwa Lichtenstein, które przyznało im stypendia. Towarzystwo to zostało założone przez artystę bez rąk - Ericha Sytegmanna, wydawało ono reprodukcje obrazów, organizowało wystawy i sprzedaż prac osób niepełnosprawnych oraz zapewniało swoim członkom skromna, comiesięczna rentę. Wanda Szuman na własny koszt sprowadziła reprodukcje obrazów około stu malarzy inwalidów z ponad dwudziestu krajów. Cierpliwie odwiedzała urząd celny, aby załatwić wszelkie formalności i uzyskać wymagane przy wywozie obrazów zezwolenia. Płótna z pracami swoich wychowanków sama nosiła na pocztę, nie były one lekkje i w czasie jednej z takich zimowych wędrówek starsza już pani upadła i złamała sobie rękę

W latach 1983 - 1985, wspólnie z rzeźbiarzem Andrzejem Wojciechowskim (obecnie profesorem pedagogiki specjalnej na UMK), organizowała cotygodniowe spotkania z dziećmi upośledzonymi w celu ich rehabilitacji oraz rozwijania ich zdolności artystycznych ${ }^{57}$. Swoją działalność w tym zakresie podsumowała kiedyś krótko: „Jak wielką radość niósł powrót każdego z nich do życia w społeczeństwie" 58 .

Wanda Szuman wspierała także działalność Koła Przyjaciół Dzieci im. Kazimierza Jeżewskiego i prowadzona przez nie akcję Przyjaciół Tworzenia Gniazd Sierocych ${ }^{59}$. Koło to istniało od listopada

${ }^{53}$ Ibidem, Sprawozdanie Zarządu Gównego PTWzK za okres od marca 1960 roku.

${ }_{55}$ L. Scibor-Rylski, Żyjemy na jednym siwiecie, "Chłopska Droga” 1979, nr 24, s. 3.

${ }^{55}$ Ibidem.

56 Ibidem, S. 4.

57 B. Dokurno, C. Iwaniszewska, op. cit., s. 122.

58 W. Stonimski, Rodziny polskie. Pasje i slawy, „Gromada Rolnik Polski” 1977, nr 136.

"K. Jeżewski (1880-1948) - pedagog, dzialacz spoleczny, reformator systemu wychowania sierot, twórca koncepcji gniazd sierocych jako zastępczych domów rodzinnych. Zalożył Towarzystwo Gniazd Sierocych. 
1957 roku, a jego głównym celem było niesienie pomocy dzieciom i uczącej się młodzieży, pozbawionej całkowicie lub częściowo opieki rodziców. W 1960 roku Koło utworzyło specjalny Społeczny Fundusz Stypendialny im. Marii Konopnickiej dla dzieci w trudnej sytuacji materialnej. Podejmowano też kroki interwencyjne w przypadkach umieszczania dzieci w szpitalach i domach dziecka, w sprawach alimentacyjnych, mieszkaniowych, egzekucyjnych itp. W 1974 roku zaliczono Wandę Szuman do Komitetu Honorowego Popierania Budowy Wiosek Dziecięcych ${ }^{60}$.

\section{Zakończenie}

Zmarła 1 grudnia 1994 roku i została pochowana w kwaterze rodzinnej na cmentarzu św. Jerzego. Za swoją działalność otrzymała wiele nagród i odznaczeń, między innymi Krzyż Kawalerski Orderu Odrodzenia Polski (1923) za swoją walkę o nauczanie języka polskiego w Regencji Kwidzyńskiej, Złota Odznakę Honorową Polskiego Związku Niewidomych (1966), Medal Polskiego Towarzystwa Walki z Kalectwem (1984), Odznakę Związku Nauczycielstwa Polskiego „Za Tajne Nauczanie” (1985), Order Uśmiechu (1986) oraz szereg odznaczeń za zasługi dla miasta Torunia uwieńczone uzyskaniem w 1992 roku Honorowego Obywatelstwa Miasta Torunia. O tym, jak duży wpływ na mieszkańców miasta wywiera nadal pamięć o jej działalności świadczy chociażby fakt, że szereg działających w nim instytucji obrało ja za swoja patronkę ${ }^{61}$.

Efekty jej pracy to nie tylko publikacje $\mathrm{i}$ instytucje założone $\mathrm{w}$ celu niesienia pomocy niepełnosprawnym, to przede wszystkim jej obecność w życiu tylu potrzebujacych wsparcia i przywrócenia nadziei na lepsze życie. To wiele osób, którym wskazała drogi samorealizacji poprzez sztukę, wydobyła $z$ apatii $\mathrm{i}$ tchnęła ducha walki o prawo do szczęścia. Oto fragment jednego $\mathrm{z}$ licznych podziękowań napływających do niej od podopiecznych, wiersz autorstwa niewidomej poetki i rzeźbiarki Józefy Budzyń-Nowakowej:

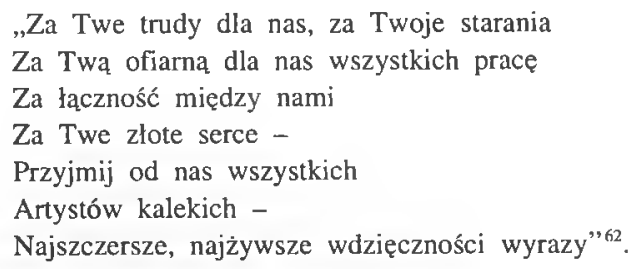

\footnotetext{
${ }^{60}$ BG UMK - DR, Spuścizıa..., sygn. 2357/III, Koło Przyjaciół Dzieci im. K. Jeżewskiego, Sprawozdanie za rok 1966 oraz z Listu Kola do W. Szuman z 12 lipca 1974 roku.

${ }^{6 !} \mathrm{Z}$ zestawienia wykonanego przez pania Cecylię Iwaniszewska.

62 L. Ścibor-Rylski, Żyjemy na jednym świecie..., s. 4.
} 